\title{
LEVEL II SCOUR ANALYSIS FOR BRIDGE 34 (RANDTH00660034) on TOWN HIGHWAY 66, crossing the SECOND BRANCH WHITE RIVER, RANDOLPH, VERMONT
}

U.S. Geological Survey Open-File Report 96-236

Prepared in cooperation with

VERMONT AGENCY OF TRANSPORTATION and

FEDERAL HIGHWAY ADMINISTRATION 


\section{LEVEL II SCOUR ANALYSIS FOR BRIDGE 34 (RANDTH00660034) on TOWN HIGHWAY 66, crossing the SECOND BRANCH WHITE RIVER, RANDOLPH, VERMONT}

By SCOTT A. OLSON and JOSEPH D. AYOTTE

U.S. Geological Survey

Open-File Report 96-236

Prepared in cooperation with

VERMONT AGENCY OF TRANSPORTATION

and

FEDERAL HIGHWAY ADMINISTRATION 


\title{
U.S. DEPARTMENT OF THE INTERIOR BRUCE BABBITT, Secretary
}

\author{
U.S. GEOLOGICAL SURVEY \\ Gordon P. Eaton, Director
}

For additional information write to:

District Chief

U.S. Geological Survey 361 Commerce Way

Pembroke, NH 03275
Copies of this report may be purchased from:

U.S. Geological Survey Earth Science Information Center Open-File Reports Section Box 25286, MS 517 Federal Center

Denver, CO 80225 


\section{CONTENTS}

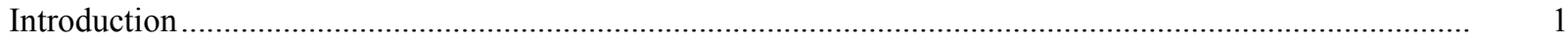

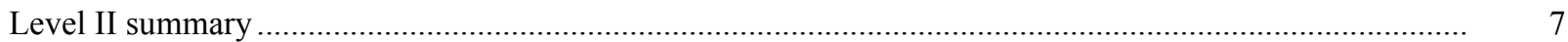

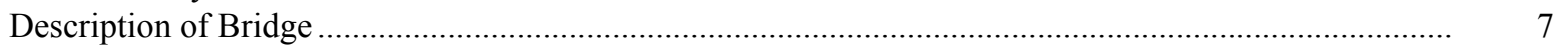

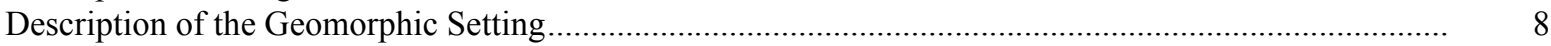

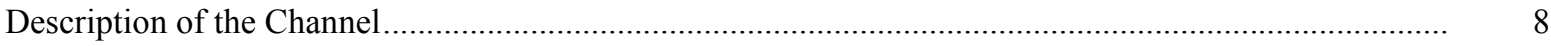

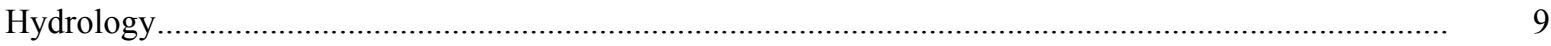

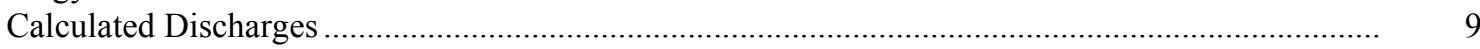

Description of the Water-Surface Profile Model (WSPRO) Analysis ......................................................... 10

Cross-Sections Used in WSPRO Analysis ......................................................................................

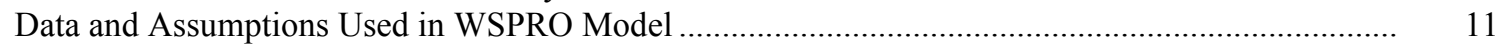

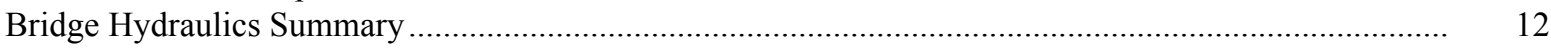

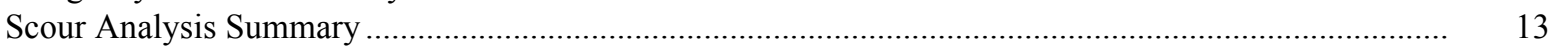

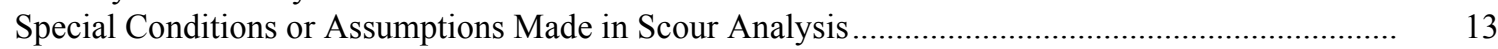

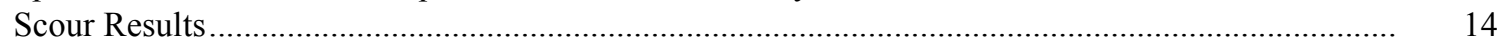

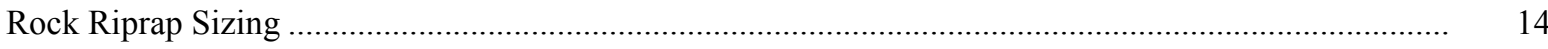

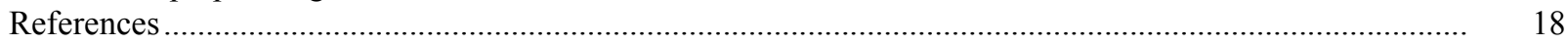

Appendixes:

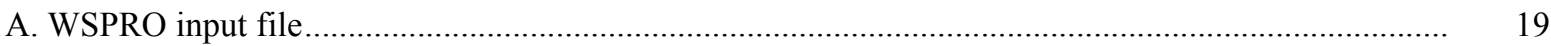

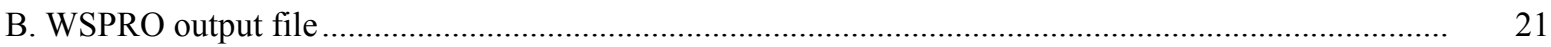

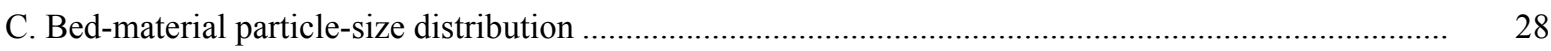

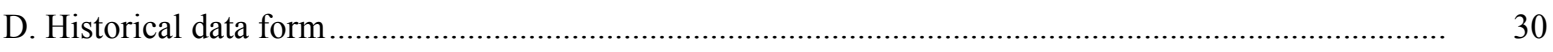

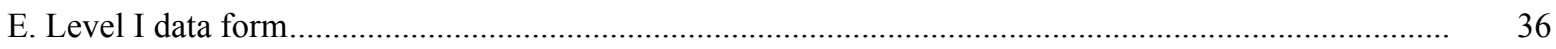

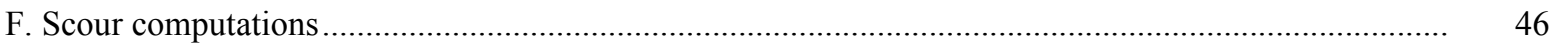

\section{FIGURES}

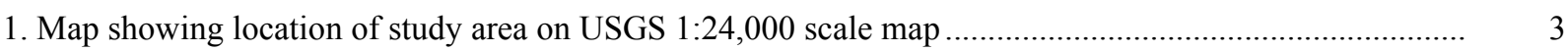

2. Map showing location of study area on Vermont Agency of Transportation town

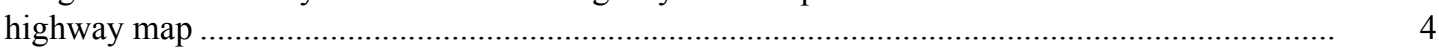

3. Structure RANDTH00660034 viewed from upstream (August 11, 1994) ………….................................. 5

4. Downstream channel viewed from structure RANDTH00660034 (August 11, 1994)............................... 5

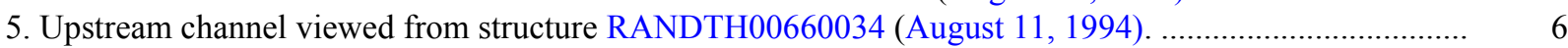

6. Structure RANDTH00660034 viewed from downstream (August 11, 1994) ........................................... 6

7. Water-surface profiles for the 100- and 500-year discharges at structure

RANDTH00660034 on Town Highway 66, crossing the Second Branch White River,

Randolph, Vermont.

8. Scour elevations for the 100- and 500-year discharges at structure

RANDTH00660034 on Town Highway 66, crossing the Second Branch White River,

Randolph, Vermont.

\section{TABLES}

1. Remaining footing/pile depth at abutments for the 100-year discharge at structure

RANDTH00660034 on Town Highway 66, crossing the Second Branch White River,

Randolph, Vermont.

2. Remaining footing/pile depth at abutments for the 500-year discharge at structure

RANDTH00660034 on Town Highway 66, crossing the Second Branch White River,

Randolph, Vermont. 


\begin{tabular}{|c|c|c|}
\hline Multiply & By & To obtain \\
\hline \multicolumn{3}{|c|}{ Length } \\
\hline inch (in.) & 25.4 & millimeter (mm) \\
\hline foot $(\mathrm{ft})$ & 0.3048 & $\operatorname{meter}(\mathrm{m})$ \\
\hline mile (mi) & 1.609 & kilometer (km) \\
\hline \multicolumn{3}{|c|}{ Slope } \\
\hline foot per mile ( $\mathrm{ft} / \mathrm{mi})$ & 0.1894 & meter per kilometer $(\mathrm{m} / \mathrm{km})$ \\
\hline \multicolumn{3}{|c|}{ Area } \\
\hline square mile $\left(\mathrm{mi}^{2}\right)$ & 2.590 & square kilometer $\left(\mathrm{km}^{2}\right)$ \\
\hline \multicolumn{3}{|c|}{ Volume } \\
\hline cubic foot $\left(\mathrm{ft}^{3}\right)$ & $\begin{array}{l}0.02832 \\
\text { Velocity and Flow }\end{array}$ & cubic meter $\left(\mathrm{m}^{3}\right)$ \\
\hline foot per second $(\mathrm{ft} / \mathrm{s})$ & 0.3048 & meter per second $(\mathrm{m} / \mathrm{s})$ \\
\hline cubic foot per second $\left(\mathrm{ft}^{3} / \mathrm{s}\right)$ & 0.02832 & cubic meter per second $\left(\mathrm{m}^{3} / \mathrm{s}\right)$ \\
\hline $\begin{array}{l}\text { cubic foot per second per } \\
\text { square mile } \\
{\left[\left(\mathrm{ft}^{3} / \mathrm{s}\right) / \mathrm{mi}^{2}\right]}\end{array}$ & 0.01093 & $\begin{array}{l}\text { cubic meter per } \\
\text { second per square } \\
\text { kilometer }\left[\left(\mathrm{m}^{3} / \mathrm{s}\right) / \mathrm{km}^{2}\right]\end{array}$ \\
\hline
\end{tabular}

OTHER ABBREVIATIONS

$\begin{array}{lrlr}\mathrm{BF} & \text { bank full } & \text { LWW } & \text { left wingwall } \\ \mathrm{cfs} & \text { cubic feet per second } & \text { MC } & \text { main channel } \\ \mathrm{D}_{50} & \text { median diameter of bed material } & \text { RAB } & \text { right abutment } \\ \mathrm{DS} & \text { downstream } & \text { RABUT } & \text { face of right abutment } \\ \mathrm{elev} & \text { elevation } & \text { RB } & \text { right bank } \\ \mathrm{f} / \mathrm{p} & \text { flood plain } & \text { ROB } & \text { right overbank } \\ \mathrm{ft} & \text { square feet } & \text { RWW } & \text { right wingwall } \\ \mathrm{ft} / \mathrm{ft} & \text { feet per foot } & \text { TH } & \text { town highway } \\ \mathrm{JCT} & \text { junction } & \text { UB } & \text { under bridge } \\ \mathrm{LAB} & \text { left abutment } & \text { US } & \text { upstream } \\ \mathrm{LABUT} & \text { face of left abutment } & \text { USGS } & \text { United States Geological Survey } \\ \text { LB } & \text { left bank } & \text { VTAOT Vermont Agency of Transportation } \\ \text { LOB } & \text { left overbank } & \text { WSPRO } & \text { water-surface profile model }\end{array}$

In this report, the words "right" and "left" refer to directions that would be reported by an observer facing downstream. Sea level: In this report, "sea level" refers to the National Geodetic Vertical Datum of 1929-- a geodetic datum derived from a general adjustment of the first-order level nets of the United States and Canada, formerly called Sea Level Datum of 1929.

In the appendices, the above abbreviations may be combined. For example, USLB would represent upstream left bank. 


\title{
LEVEL II SCOUR ANALYSIS FOR BRIDGE 34 (RANDTH00660034) ON TOWN HIGHWAY 66, CROSSING THE SECOND BRANCH WHITE RIVER, RANDOLPH, VERMONT
}

\author{
By Scott A. Olson and Joseph D. Ayotte
}

\section{INTRODUCTION}

This report provides the results of a detailed Level II analysis of scour potential at structure RANDTH00660034 on town highway 66 crossing the Second Branch White River, Randolph, Vermont (figures 1-8). A Level II study is a basic engineering analysis of the site, including a quantitative analysis of stream stability and scour (U.S. Department of Transportation, 1993). A Level I study is included in Appendix E of this report. A Level I study provides a qualitative geomorphic characterization of the study site. Information on the bridge available from VTAOT files was compiled prior to conducting Level I and Level II analyses and can be found in Appendix D.

The site is in the Green Mountain physiographic division of central Vermont in the town of Randolph. The $51.3-\mathrm{mi}^{2}$ drainage area is in a predominantly rural basin. In the vicinity of the study site, the left and right banks are covered by fields with some brush on the upstream left and downstream right banks and with row crops on the downstream left overbank.

In the study area, the Second Branch White River has a sinuous channel with a slope of approximately $0.002 \mathrm{ft} / \mathrm{ft}$, an average channel top width of $60 \mathrm{ft}$ and an average channel depth of $7 \mathrm{ft}$. The predominant channel bed material is sand $\left(\mathrm{D}_{50}\right.$ is $1.34 \mathrm{~mm}$ or $\left.0.0044 \mathrm{ft}\right)$. The geomorphic assessment at the time of the Level I and Level II site visit on August 11, 1994, indicated that the reach was laterally unstable. Channel scour is evident along the left half of the channel from about 30 feet upstream to about 20 feet downstream of the bridge. There is a cut bank with block failures along the left bank upstream of the bridge further indicating instability of the stream reach.

The town highway 66 crossing of the Second Branch White River is a 57-ft-long, one-lane covered bridge consisting of one 45-foot span (Vermont Agency of Transportation, written communication, July 29,1994$)$. The bridge is supported by vertical, concrete abutments with one wingwall on the upstream left side. The base of the left abutment was protected by type-1 stone fill (less than 12 inches diameter). The channel is skewed approximately 40 degrees to the opening while the opening-skew-to-roadway is 45 degrees. Additional details describing conditions at the site are included in the Level II Summary and Appendices D and $\mathrm{E}$. 
Scour depths and rock rip-rap sizes were computed using the general guidelines described in Hydraulic Engineering Circular 18 (Richardson and others, 1993).

Total scour at a highway crossing is comprised of three components: 1) long-term aggradation or degradation; 2) contraction scour (due to reduction in flow area caused by a bridge) and; 3) local scour (caused by accelerated flow around piers and abutments). Total scour is the sum of the three components. Equations are available to compute scour depths for contraction and local scour and a summary of the results follows.

Contraction scour for all modelled flows ranged from $6.3 \mathrm{ft}$ to $7.8 \mathrm{ft}$ and the worst-case contraction scour occurred at the 100-year discharge. Abutment scour ranged from $7.9 \mathrm{ft}$ to $20.3 \mathrm{ft}$ and the worst-case abutment scour occurred at the 500-year discharge. Scour depths and depths to armoring are summarized on p. 14 in the section titled "Scour Results".

Scour elevations, based on the calculated depths are presented in tables 1 and 2; a graph of the scour elevations is presented in figure 8 Scour depths were calculated assuming an infinite depth of erosive material and a homogeneous particle-size distribution.

For all scour presented in this report, "the scour depths adopted [by VTAOT] may differ from the equation values based on engineering judgement" (Richardson and others, 1993, p. 21, 27). It is generally accepted that the Froehlich equation (abutment scour) gives "excessively conservative estimates of scour depths" (Richardson and others, 1993, p. 48). Many factors, including historical performance during flood events, the geomorphic assessment, and the results of the hydraulic analyses, must be considered to properly assess the validity of abutment scour results. 


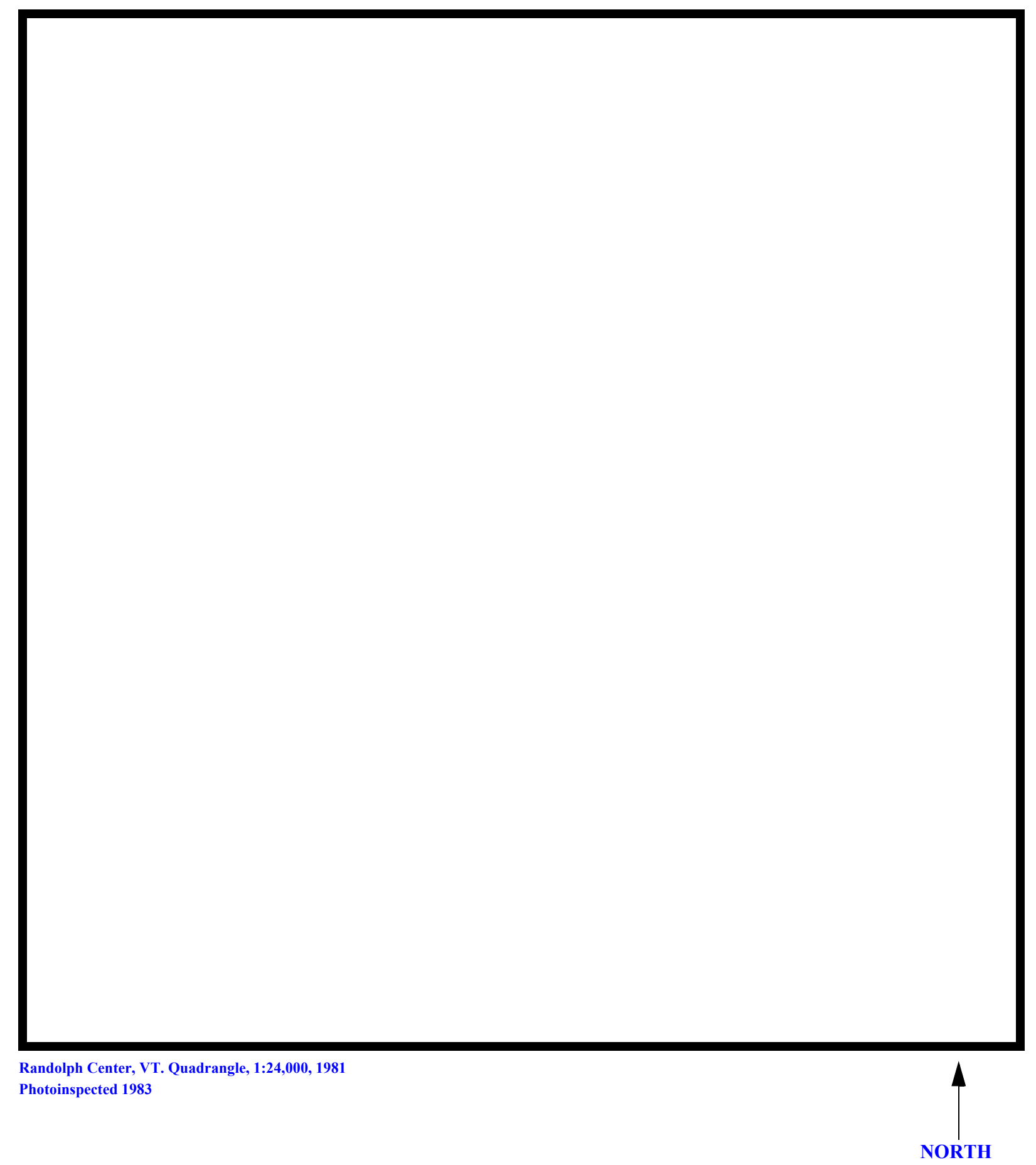

Figure 1. Location of study area on USGS 1:24,000 scale map. 
Figure 2. Location of study area on Vermont Agency of Transportation town highway map. 

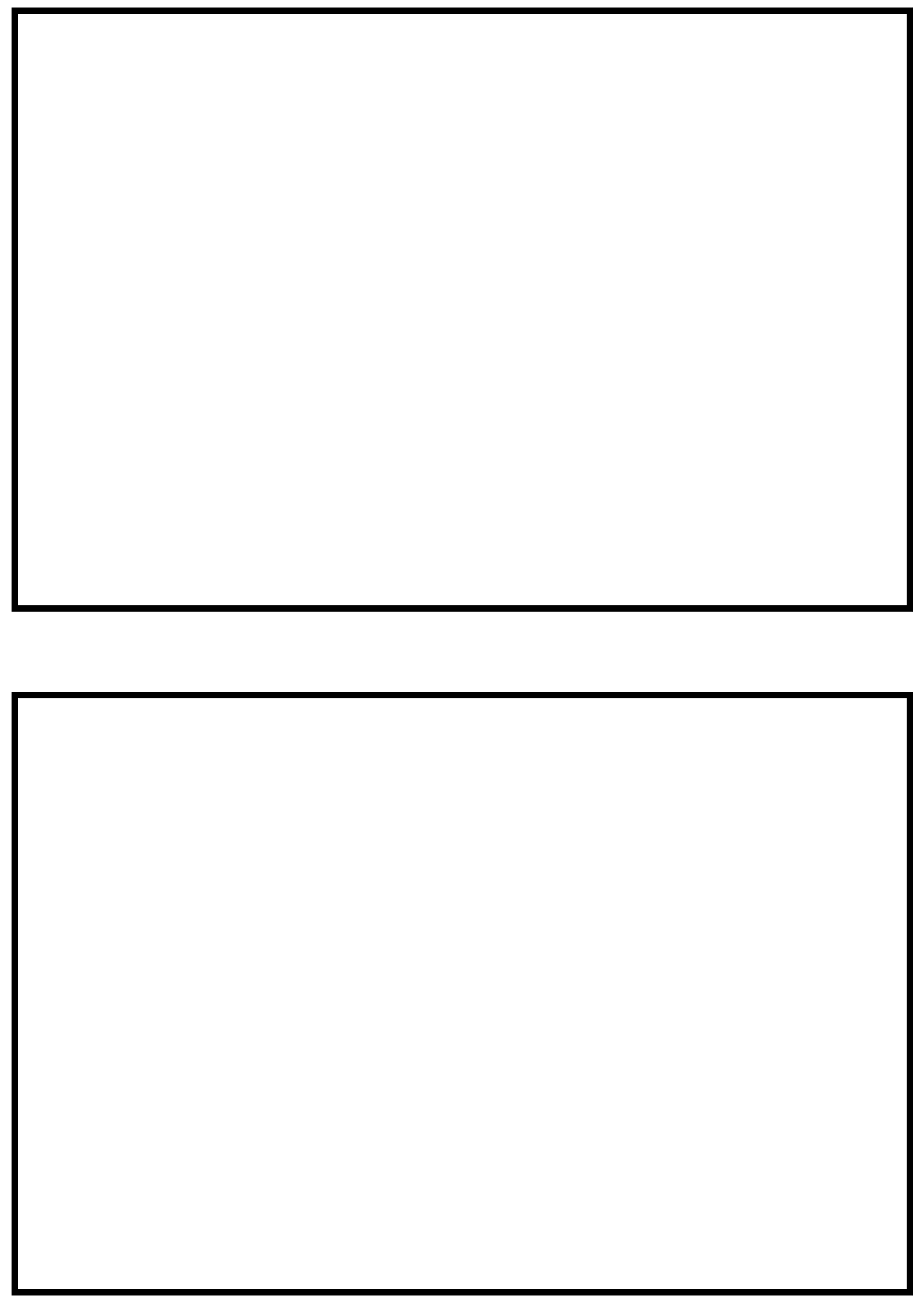

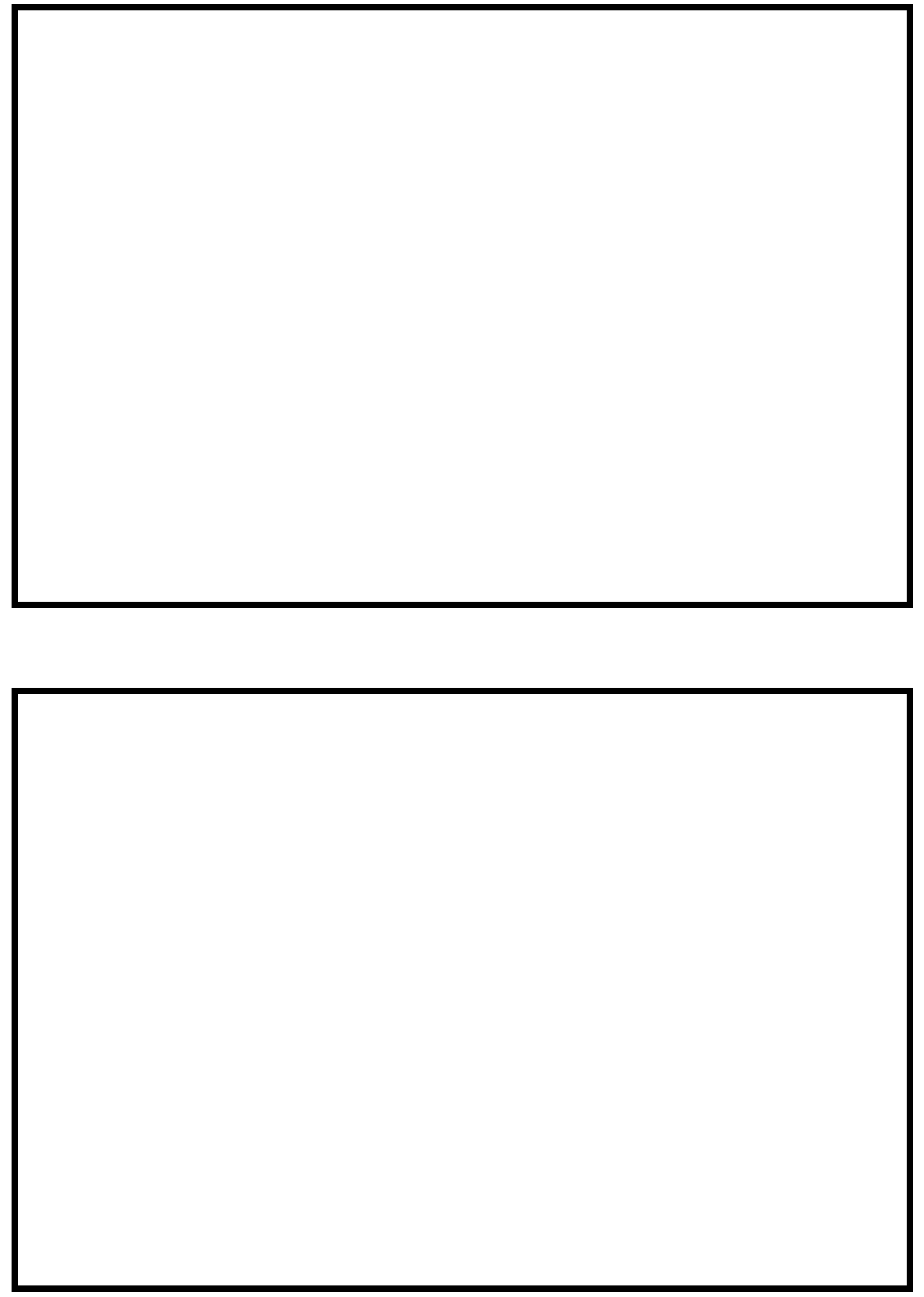


\section{LEVEL II SUMMARY}

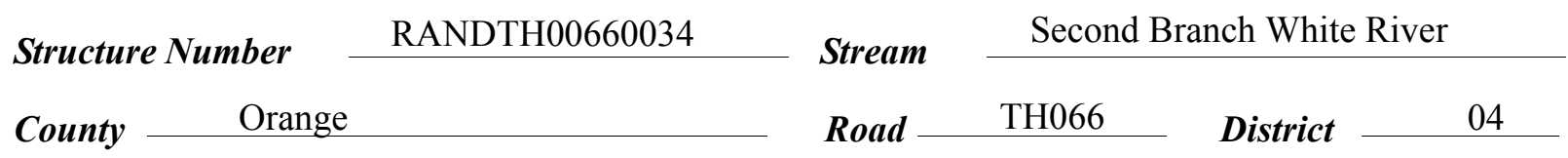

\section{Description of Bridge}

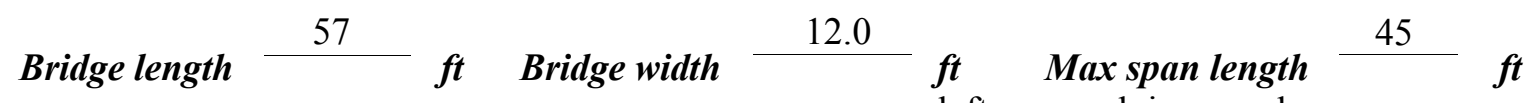
Alignment of bridge to road (on curve or straight) laid-up stone Abutment type

Stone fill on abutment? on left Embankment type left approach is curved vertical 08/11/94 nacmintin... af nta... sill. type I stone fill along base of left abutment, some of which has slumped into the channel.

Abutments are stone with one wing wall on the

upstream left bank

\section{$\mathrm{Y}$}

Is bridge skewed to flood flow according to $\mathrm{Y} \quad$ ' survey?

Angle

The skew angle of the stream to the bridge is up to 30 degrees. Opening skew to roadway, is 10 degrees and the left abutment is attacked at approximately 40 degrees

Debris accumulation on bridge at time of Level I or Level II site visit:

\begin{tabular}{|c|c|c|c|}
\hline & $\begin{array}{c}\text { Date of incmortion } \\
08 / 11 / 94 \\
\end{array}$ & $\begin{array}{l}\text { Percent of rbminal } \\
\text { blocked inortzontally }\end{array}$ & $\begin{array}{l}\text { Percent of } 0 \\
\text { blocked verticatty }\end{array}$ \\
\hline Level I & same & - & - \\
\hline & High, due & es on the unstable banks & \\
\hline
\end{tabular}

\section{Potential for debris}

August 11, 1994: Some minor debris existed in the bridge opening blocking an insignificant Doscriho anv foaturos noar ar at tho hridoo that mav, affort flow, (includo ahsorvation datol percentage of the opening. The left abutment protrudes into the low-water channel. This is a covered bridge, thus flow over the bridge deck does not occur 


\section{Description of the Geomorphic Setting}

General topography The bridge is in an approximately 200-300 ft-wide, flat valley over a very sinuous stream.

Geomorphic conditions at bridge site: downstream (DS), upstream (US)

Date of inspection $\quad 08 / 11 / 94$

DS left: $\quad$ moderate flood plain to steep valley wall

DS right: $\quad$ moderately steep valley wall

US left: $\quad$ moderate flood plain to steep valley wall

US right: flood plain to moderately steep valley wall

\section{Description of the Channel}

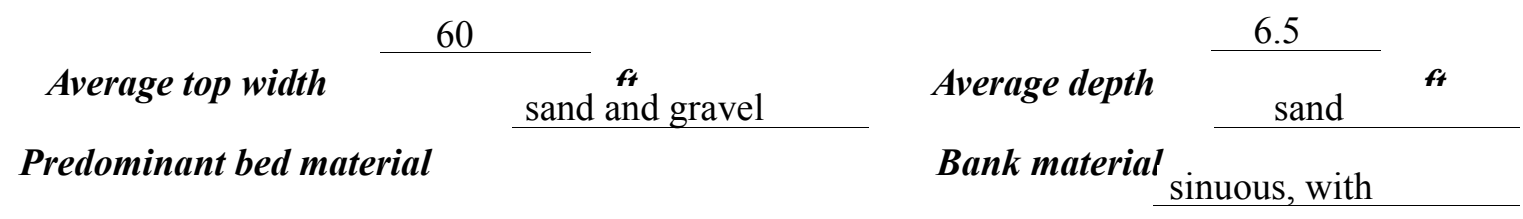

moderately wide flood plains. It is alluvial and laterally unstable

$08 / 11 / 94$

Vegetative co ${ }^{1}$ row crops with some brush on immediate banks

DS left: $\quad$ scattered brush in an otherwise open field

DS right: brush on immediate banks changing to forest at the valley wall

US left: $\quad$ pasture

US right: $\quad \underline{\mathrm{N}}$

Do banks appear stable? 08/11/94--Moderate fluvial erosion has occurred on the upstream left

bank due to flow impact. Light fluvial erosion was observed on the downstream right bank.
date of observatton.

On $08 / 11 / 94$, there was a minor amount of debris near the downstream end of the left abutment.

The left abutment

protrudes into the low-water channel.

Describe any obstructions in channel and date of observation. 


\title{
Hydrology
}

Drainage area $\quad 51.3 \boldsymbol{m i}^{2}$

Percentage of drainage area in physiographic provinces: (approximate)

Physiographic province

Green Mountain
Percent of drainage area

100

\begin{abstract}
Is drainage area considered rural or urban?
Rural None

urbanization:

Describe any significant
\end{abstract}

Is there a USGS gage on the stream of interest?

No

USGS gage description

USGS gage number

Gage drainage area $\mathrm{mi}^{2}$

\begin{tabular}{|c|c|c|c|c|c|c|c|c|c|c|}
\hline \multirow[b]{3}{*}{ Is thore a lakeln } & \multirow{2}{*}{\multicolumn{2}{|c|}{$\begin{array}{l}\text { USGS gage number } \\
\text { Gage drainage area }\end{array}$}} & \multicolumn{3}{|c|}{-- } & \multirow{2}{*}{\multicolumn{3}{|c|}{$m i^{2}$}} & & \multirow[b]{2}{*}{ No } \\
\hline & & & & & & & & & & \\
\hline & $\therefore$ & $\cdots \cdot \cdots$ & $m$ & $\cdot$ & • & . & 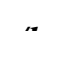 & " &.$\quad$. & \\
\hline
\end{tabular}

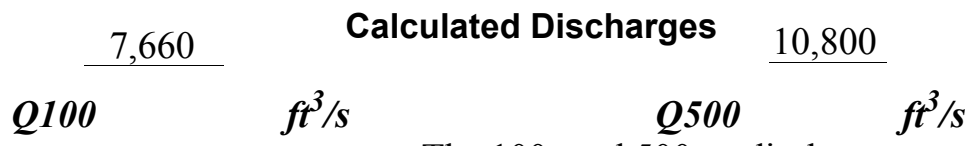

The 100- and 500-yr discharges were determined

from a drainage area relationship with an upstream site. The upstream site had a drainage area of 46 square miles and a 100-yr discharge, determined from a previous study by VTAOT, of 7100 cfs (Landry, D., oral communication, March 1995). The 500-yr discharge at the upstream site was found by graphically extrapolating flood frequency estimates determined in the previous study. Incipient road overflow discharge was determined to be $2,750 \mathrm{cfs}$. 


\section{Description of the Water-Surface Profile Model (WSPRO) Analysis}

Datum for WSPRO analysis (USGS survey, sea level, VTAOT plans)

USGS survey

Datum tie between USGS survey and VTAOT plans

N/A

Description of reference marks used to determine USGS datum. $\quad$ RM1 is a chiseled

square in the top of the uppermost stone of the left abutment on the downstream side of the

bridge; the arbitrary elevation is 499.52 feet, arbitrary datum.

\section{Cross-Sections Used in WSPRO Analysis}

\begin{tabular}{cccl}
\hline${ }^{1}$ Cross-section & $\begin{array}{c}\text { Section } \\
\text { Reference } \\
\text { Distance } \\
(\text { SRD) } \text { in feet }\end{array}$ & $\begin{array}{c}{ }^{2} \text { Cross-section } \\
\text { development }\end{array}$ & \multicolumn{1}{c}{ Comments } \\
\hline EXITX & 0 & 1 & $\begin{array}{l}\text { Exit section } \\
\text { Downstream Full-valley } \\
\text { section (Templated from } \\
\text { FULLV }\end{array}$ \\
BRIDG & 57 & 2 & $\begin{array}{l}\text { BXididge section } \\
\text { Road Grade section }\end{array}$ \\
RDWAY & 57 & 1 & $\begin{array}{l}\text { Approach section (as sur- } \\
\text { APPRO }\end{array}$ \\
\hline
\end{tabular}

${ }^{1}$ For location of cross-sections see plan-view sketch included with Level I field form, Appendix E. For more detail on how cross-sections were developed see WSPRO input file. 


\section{Data and Assumptions Used in WSPRO Model}

Hydraulic analyses of the reach were done by use of the Federal Highway Administration's WSPRO step-backwater computer program (Shearman and others, 1986, and Shearman, 1990). The analysis reported herein reflects conditions existing at the site at the time of the study. Furthermore, in the development of the model it was necessary to assume no accumulation of debris or ice at the site. Results of the hydraulic model are presented in the Bridge Hydraulic Summary, Appendix B, and figure 7.

Channel roughness factors (Manning's " $n$ ") used in the hydraulic model were estimated using field inspections at each cross section following the general guidelines described by Arcement, Jr. and Schneider (1989). Final adjustments to the values were made during the modelling of the reach. Channel " $\mathrm{n}$ " values for the reach ranged from 0.030 to 0.038 , and overbank " $n$ " values were 0.036 .

Normal depth at the exit section (EXITX) was assumed as the starting water surface. This depth was computed by use of the slope-conveyance method outlined in the User's manual for WSPRO (Shearman, 1990). The slope used was $0.0038 \mathrm{ft} / \mathrm{ft}$ which was measured from water surface profiles for the Second Branch White River in the Flood Insurance Study for the Town of Randolph (Federal Emergency Management Agency, 1991).

The surveyed approach section was moved to establish the modelled approach section (APPRO), one bridge length upstream of the upstream face as recommended by Shearman and others (1986). This approach also provides a consistent method for determining scour variables. 


\title{
Bridge Hydraulics Summary
}

\author{
Average bridge embankment elevation $\quad 501.3 \quad f t$ \\ Average low steel elevation \\ $498.4 \quad f t$
}

100-year discharge $\quad 7660 \quad \mathrm{ft}^{3} / \mathrm{s}$

Water-surface elevation in bridge opening $\quad 498.6 f t$

Road overtopping? __ Y Discharge over road

$4170 \ldots$

Area of flow in bridge opening $295 \quad \mathrm{ft}^{2}$

Average velocity in bridge opening $11.8 \mathrm{ft} / \mathrm{s}$

Maximum WSPRO tube velocity at bridge $\quad 14.5 \mathrm{ft} / \mathrm{s}$

Water-surface elevation at Approach section with bridge

Water-surface elevation at Approach section without bridge

505.1

Amount of backwater caused by bridge

$3.1 \quad \boldsymbol{t}$

500-year discharge $\quad 10800 \quad f^{3} / s$

Water-surface elevation in bridge opening

$498.6 f t$

Road overtopping?

Y Discharge over road

$7300, / 5$

Area of flow in bridge opening $\quad 295 \quad \mathrm{ft}^{2}$

Average velocity in bridge opening $\quad 11.9 \mathrm{ft} / \mathrm{s}$

Maximum WSPRO tube velocity at bridge 14.6_'s

Water-surface elevation at Approach section with bridge

506.5

Water-surface elevation at Approach section without bridge

Amount of backwater caused by bridge 2.9 .

Incipient overtopping discharge $\quad 2,750 \quad \mathrm{ft}^{3} / \mathrm{s}$

Water-surface elevation in bridge opening 498.6 t

Area of flow in bridge opening

$295 \mathrm{ft}^{2}$

Average velocity in bridge opening $\quad 9.3 \quad \mathrm{ft} / \mathrm{s}$

Maximum WSPRO tube velocity at bridge $\quad 11.4 \quad \mathrm{ft} / \mathrm{s}$

Water-surface elevation at Approach section with bridge

Water-surface elevation at Approach section without bridge

Amount of backwater caused by bridge $\quad 1.8$ it

500.8

499.0 


\section{Scour Analysis Summary}

\section{Special Conditions or Assumptions Made in Scour Analysis}

Scour depths were computed using the general guidelines described in Hydraulic Engineering Circular 18 (Richardson and others, 1993). Scour depths were calculated assuming an infinite depth of erosive material and a homogeneous particle-size distribution. The results of the scour analysis are presented in tables 1 and 2 and a graph of the scour depths is presented in figure 8 .

Contraction scour was computed by use of the live-bed contraction scour equation (Richardson and others, 1993, p. 33, equation 16) for the 100-year, 500-year, and incipient road-overflow discharges. For contraction scour computations, the average depth in the contracted section (AREA/TOPWIDTH) is subtracted from the depth of flow computed by the scour equation (Y2) to determine the actual amount of scour. The 100-year, 500-year and incipient road-overflow discharges resulted in submerged orifice flow. The results of Chang's contraction scour (Richardson and others, 1995, p. 145-146) for all the modeled events were also computed and can be found in appendix F. Because the Chang equation for pressure-flow scour was derived solely with data for clear-water scour, it is not currently understood how well it would predict in live-bed conditions. Therefore, although pressure flow conditions exist for all of the modelled flows, the reported scour depths were computed using Laursen's live-bed contraction scour equation.

Abutment scour was computed by use of the HIRE equation (Richardson and others, 1993, p. 50, equation 25) because the HIRE equation is recommended when the length to depth ratio of the embankment blocking flow exceeds 25. Variables for the HIRE equation include the Froude number of the flow approaching the embankments, the length of the embankment blocking flow, and the depth of flow approaching the embankment less any roadway overtopping.

It should be noted that the worst-case contraction scour and total scour resulted from the 100 -yr event. 


\section{Scour Results}

$$
\text { 100-yr discharge 500-yr discharge }
$$

Contraction scour:

Main channel

Live-bed scour

Clear-water scour

Depth to armoring

Left overbank

Right overbank

Local scour:

Abutment scour

Left abutment

Right abutment

Pier scour

Pier 1

Pier 2

Pier 3
(Scour depths in feet)

Incipient
chtopping
charge 


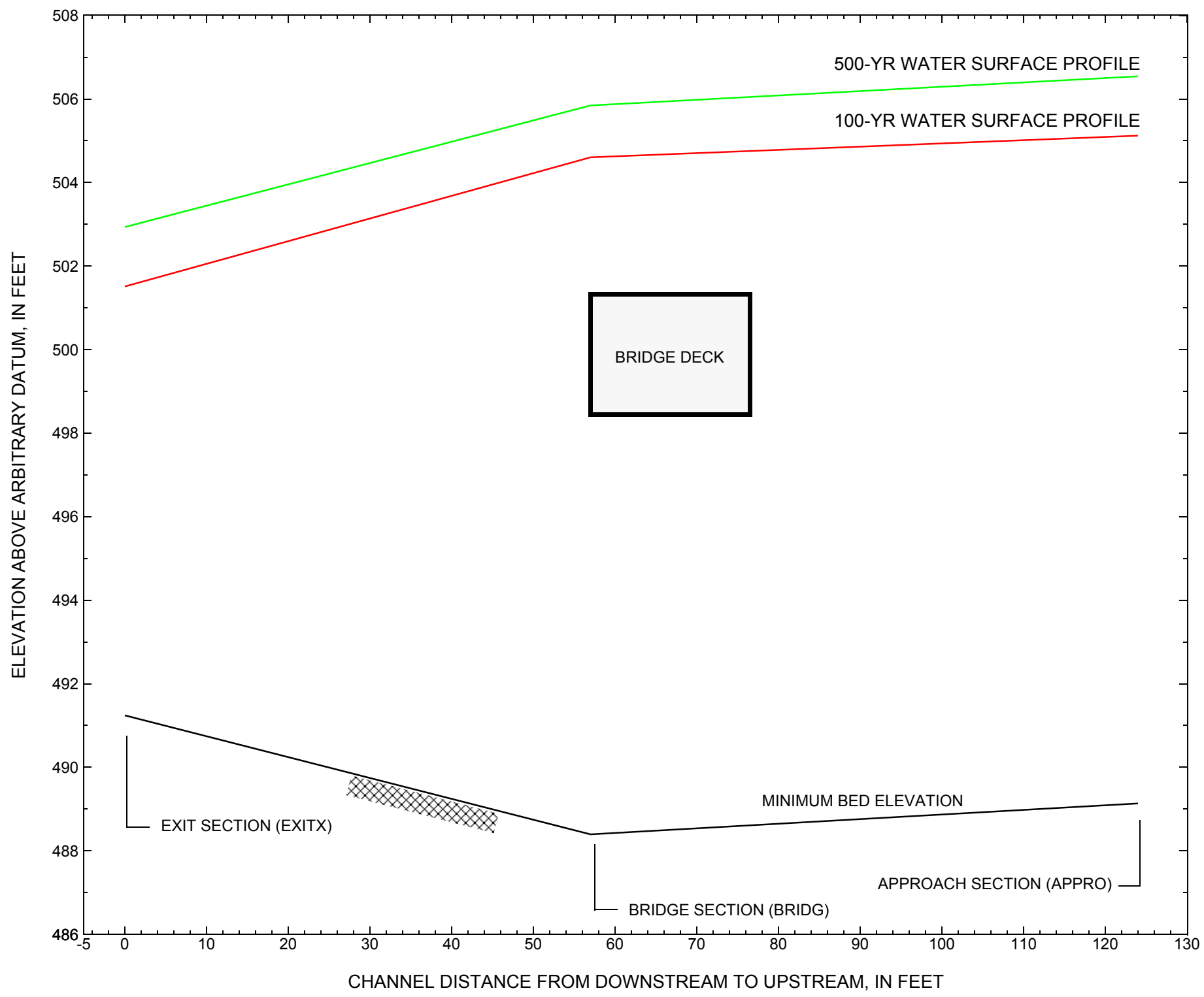

Figure 7. Water-surface profiles for the 100- and 500-yr discharges at structure RANDTH00660034 on town highway 66, crossing the Second Branch White River, Randolph, Vermont. 


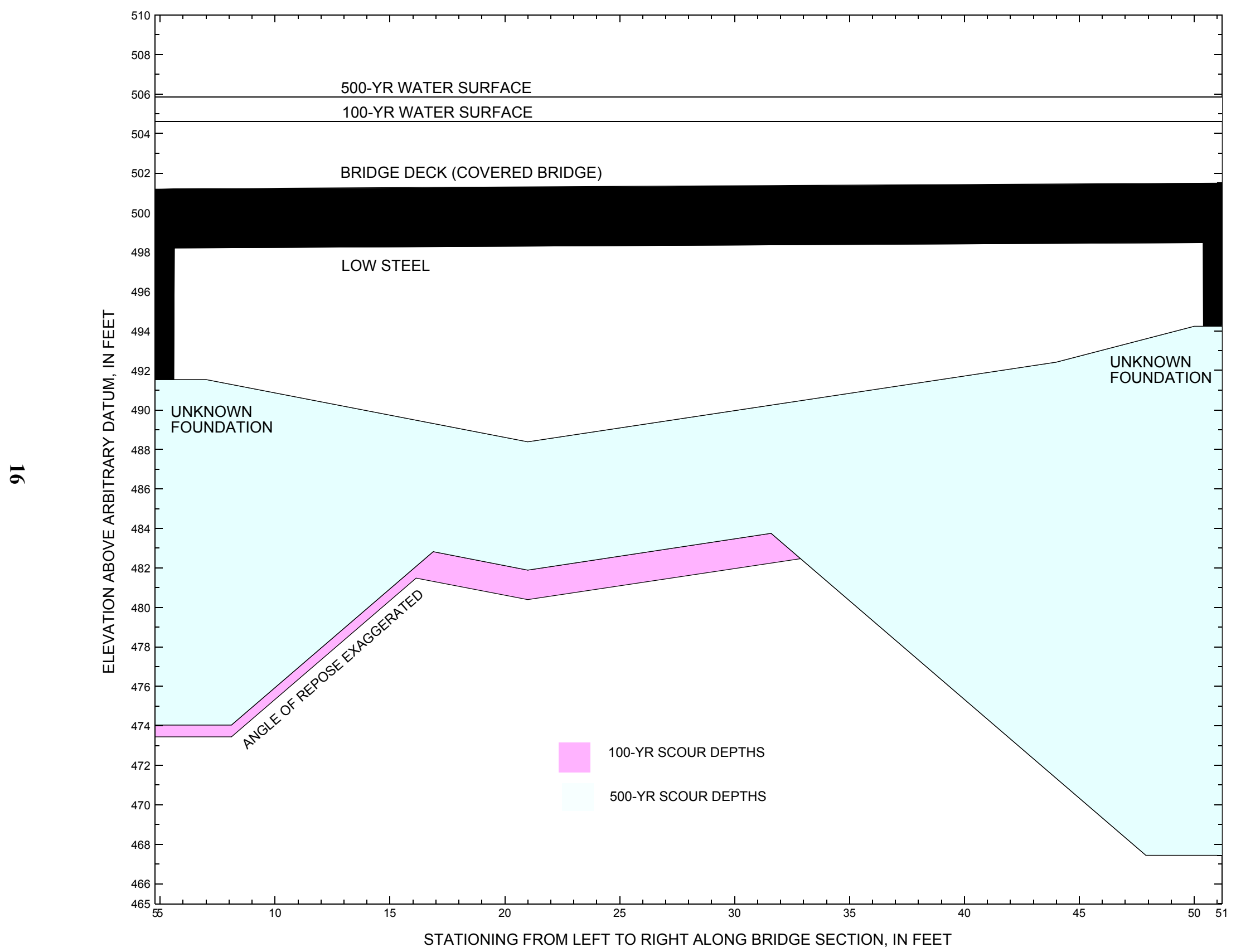

Figure 8. Scour elevations for the 100-yr and 500-yr discharges at structure RANDTH00660034 on town highway 66, crossing the Second Branch White River, Randolph, Vermont. 


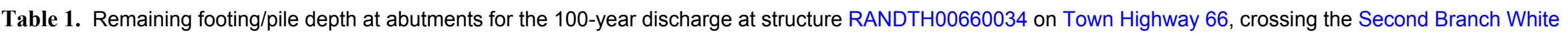
River, Randolph, Vermont.

[VTAOT, Vermont Agency of Transportation; --,no data]

\begin{tabular}{|c|c|c|c|c|c|c|c|c|c|c|c|}
\hline Description & Station $^{1}$ & $\begin{array}{l}\text { VTAOT } \\
\text { minimum } \\
\text { low-chord } \\
\text { elevation } \\
\text { (feet) }\end{array}$ & $\begin{array}{c}\text { Surveyed } \\
\text { minimum } \\
\text { low-chord } \\
\text { elevation }{ }^{2} \\
\text { (feet) }\end{array}$ & $\begin{array}{c}\text { Bottom of } \\
\text { footing } \\
\text { elevation } \\
\text { (feet) }\end{array}$ & $\begin{array}{c}\text { Channel } \\
\text { elevation at } \\
\text { abutment/ } \\
\text { pier }^{2} \\
\text { (feet) }\end{array}$ & $\begin{array}{l}\text { Contraction } \\
\text { scour depth } \\
\text { (feet) }\end{array}$ & $\begin{array}{l}\text { Abutment } \\
\text { scour } \\
\text { depth } \\
\text { (feet) }\end{array}$ & $\begin{array}{l}\text { Pier } \\
\text { scour } \\
\text { depth } \\
\text { (feet) }\end{array}$ & $\begin{array}{l}\text { Depth of } \\
\text { total scour } \\
\text { (feet) }\end{array}$ & $\begin{array}{c}\text { Elevation of } \\
\text { scour }^{2} \\
\text { (feet) }\end{array}$ & $\begin{array}{c}\text { Remaining } \\
\text { footing/pile } \\
\text { depth } \\
\text { (feet) }\end{array}$ \\
\hline \multicolumn{12}{|c|}{100 -yr. discharge is 7,660 cubic-feet per second } \\
\hline Left abutment & 5 & -- & 498.1 & -- & 491.5 & 7.8 & 10.1 & -- & 17.9 & 473.6 & -- \\
\hline Right abutment & 51 & -- & 498.6 & -- & 494.2 & 7.8 & 18.7 & -- & 26.5 & 467.7 & -- \\
\hline
\end{tabular}

1. Measured along the face of the most constricting side of the bridge.

2. Arbitrary datum for this study.

Table 2. Remaining footing/pile depth at abutments for the 500-year discharge at structure RANDTH00660034 on Town Highway 66, crossing the Second Branch White River, Randolph, Vermont.

[VTAOT, Vermont Agency of Transportation; --, no data]

\begin{tabular}{|c|c|c|c|c|c|c|c|c|c|c|c|}
\hline Description & Station $^{1}$ & $\begin{array}{l}\text { VTAOT } \\
\text { minimum } \\
\text { low-chord } \\
\text { elevation } \\
\text { (feet) }\end{array}$ & $\begin{array}{l}\text { Surveyed } \\
\text { minimum } \\
\text { low-chord } \\
\text { elevation } \\
\text { (feet) }\end{array}$ & $\begin{array}{l}\text { Bottom of } \\
\text { footing } \\
\text { elevation } \\
\text { (feet) }\end{array}$ & $\begin{array}{c}\text { Channel } \\
\text { elevation at } \\
\text { abutment/ } \\
\text { pier }^{2} \\
\text { (feet) }\end{array}$ & $\begin{array}{l}\text { Contraction } \\
\text { scour depth } \\
\text { (feet) }\end{array}$ & $\begin{array}{l}\text { Abutment } \\
\text { scour } \\
\text { depth } \\
\text { (feet) }\end{array}$ & $\begin{array}{l}\text { Pier } \\
\text { scour } \\
\text { depth } \\
\text { (feet) }\end{array}$ & $\begin{array}{l}\text { Depth of } \\
\text { total scour } \\
\text { (feet) }\end{array}$ & $\begin{array}{c}\text { Elevation of } \\
\text { scour }^{2} \\
\text { (feet) }\end{array}$ & $\begin{array}{c}\text { Remaining } \\
\text { footing/pile } \\
\text { depth } \\
\text { (feet) }\end{array}$ \\
\hline \multicolumn{12}{|c|}{500 -yr. discharge is 10,800 cubic-feet per second } \\
\hline Left abutment & 5 & -- & 498.1 & -- & 491.5 & 6.3 & 11.0 & -- & 17.3 & 474.2 & -- \\
\hline Right abutment & 51 & -- & 498.6 & -- & 494.2 & 6.3 & 20.3 & -- & 26.6 & 467.6 & -- \\
\hline
\end{tabular}

1. Measured along the face of the most constricting side of the bridge.

2. Arbitrary datum for this study. 


\section{SELECTED REFERENCES}

Arcement, G.J., Jr., and Schneider, V.R., 1989, Guide for selecting Manning's roughness coefficients for natural channels and flood plains: U.S. Geological Survey Water-Supply Paper 2339, 38 p.

Barnes, H.H., Jr., 1967, Roughness characteristics of natural channels: U.S. Geological Survey Water-Supply Paper 1849, 213 p.

Brown, S.A. and Clyde, E.S., 1989, Design of riprap revetment: Federal Highway Administration Hydraulic Engineering Circular No. 11, Publication FHWA-IP-89-016, 156 p.

Federal Emergency Management Agency, 1991, Flood Insurance Study, Town of Randolph, Orange County, Vermont: Washington, D.C., July 16, 1991.

Froehlich, D.C., 1989, Local scour at bridge abutments in Ports, M.A., ed., Hydraulic Engineering--Proceedings of the 1989 National Conference on Hydraulic Engineering: New York, American Society of Civil Engineers, p. 13-18.

Hayes, D.C.,1993, Site selection and collection of bridge-scour data in Delaware, Maryland, and Virginia: U.S. Geological Survey WaterResources Investigation Report 93-4017, 23 p.

Interagency Advisory Committee on Water Data, 1982, Guidelines for determining flood flow frequency: U.S. Geological Survey, Bulletin 17B of the Hydrology Subcommittee, 190 p.

Johnson, C.G. and Tasker, G.D.,1974, Progress report on flood magnitude and frequency of Vermont streams: U.S. Geological Survey Open-File Report 74-130, 37 p.

Lagasse, P.F., Schall, J.D., Johnson, F., Richardson, E.V., Richardson, J.R., Chang, F., 1991, Stream Stability at Highway Structures: Federal Highway Administration Hydraulic Engineering Circular No. 20, Publication FHWA-IP-90-014, 195 p.

Laursen, E.M., 1960, Scour at bridge crossings: Journal of the Hydraulics Division, American Society of Civil Engineers, v. 86, no. HY2, p. 39-53.

Richardson, E.V. and Davis, S.R., 1995, Evaluating scour at bridges: Federal Highway Administration Hydraulic Engineering Circular No. 18, Publication FHWA-IP-90-017, 204 p.

Richardson, E.V., Harrison, L.J., Richardson, J.R., and Davis, S.R., 1993, Evaluating scour at bridges: Federal Highway Administration Hydraulic Engineering Circular No. 18, Publication FHWA-IP-90-017, 131 p.

Richardson, E.V., Simons, D.B., and Julien, P.Y., 1990, Highways in the river environment: Federal Highway Administration Publication FHWA-HI-90-016.

Ritter, D.F., 1984, Process Geomorphology: W.C. Brown Co., Debuque, Iowa, 603 p.

Shearman, J.O., 1990, User's manual for WSPRO--a computer model for water surface profile computations: Federal Highway Administration Publication FHWA-IP-89-027, 187 p.

Shearman, J.O., Kirby, W.H., Schneider, V.R., and Flippo, H.N., 1986, Bridge waterways analysis model; research report: Federal Highway Administration Publication FHWA-RD-86-108, 112 p.

U.S. Department of Transportation, 1993, Stream stability and scour at highway bridges, Participant Workbook: Federal Highway Administration Publication FHWA HI-91-011.

U.S. Geological Survey, 1981, Randolph Center, Vermont 7.5 Minute Series quadrangle map: U.S. Geological Survey Topographic Maps, Photoinspected 1983, Scale 1:24,000. 


\section{APPENDIX A: \\ WSPRO INPUT FILE}




\section{WSPRO INPUT FILE}

$\mathrm{BR}$

GR

GR

CD

$\mathrm{N}$

$\mathrm{XR}$

GR

GR

GR

GR

$\mathrm{BP}$

*

GR

GR

GR

GR

GR

$\mathrm{N}$

SA

BP

*

HP 1 APPRO 505.12 1505.12

$\mathrm{HP} 2$ APPRO 505.12 * *7660

HP 2 RDWAY 504.60 * * 4168

$\mathrm{HP} 1 \mathrm{BRIDG} 498.651498 .65$

HP 2 BRIDG 498.65 * * 3491

*

HP 1 APPRO 506.541506 .54

HP 2 APPRO 506.54* * 10800

HP 2 RDWAY 505.84 * * 7305

HP 1 BRIDG 498.651498 .65

HP 2 BRIDG 498.65 * 3503

\begin{tabular}{|c|c|c|c|c|}
\hline-119. & 502.11 & -113. & 498.45 & $-93 ., 498.31$ \\
\hline-22 & 496.77 & -13. & 498.01 & 495.71 \\
\hline & 491.81 & 33. & 491.24 & 491.94 \\
\hline & 500.82 & 88. & 506.91 & \\
\hline
\end{tabular}
0.038

$$
7 ., 491.54
$$

$21 ., 488.39$

$44 ., 492.42$

$51 ., 498.65$

$$
\text { 5. } 498.09
$$

$-74 ., 501.08$

$-49 ., 500.88$

$5 ., 512$.

$60 ., 512$.

$5 ., 501.13$

$183 ., 504.51$

$199 ., 506.90$

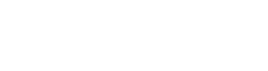




\section{APPENDIX B: \\ WSPRO OUTPUT FILE}


WSPRO OUTPUT FILE

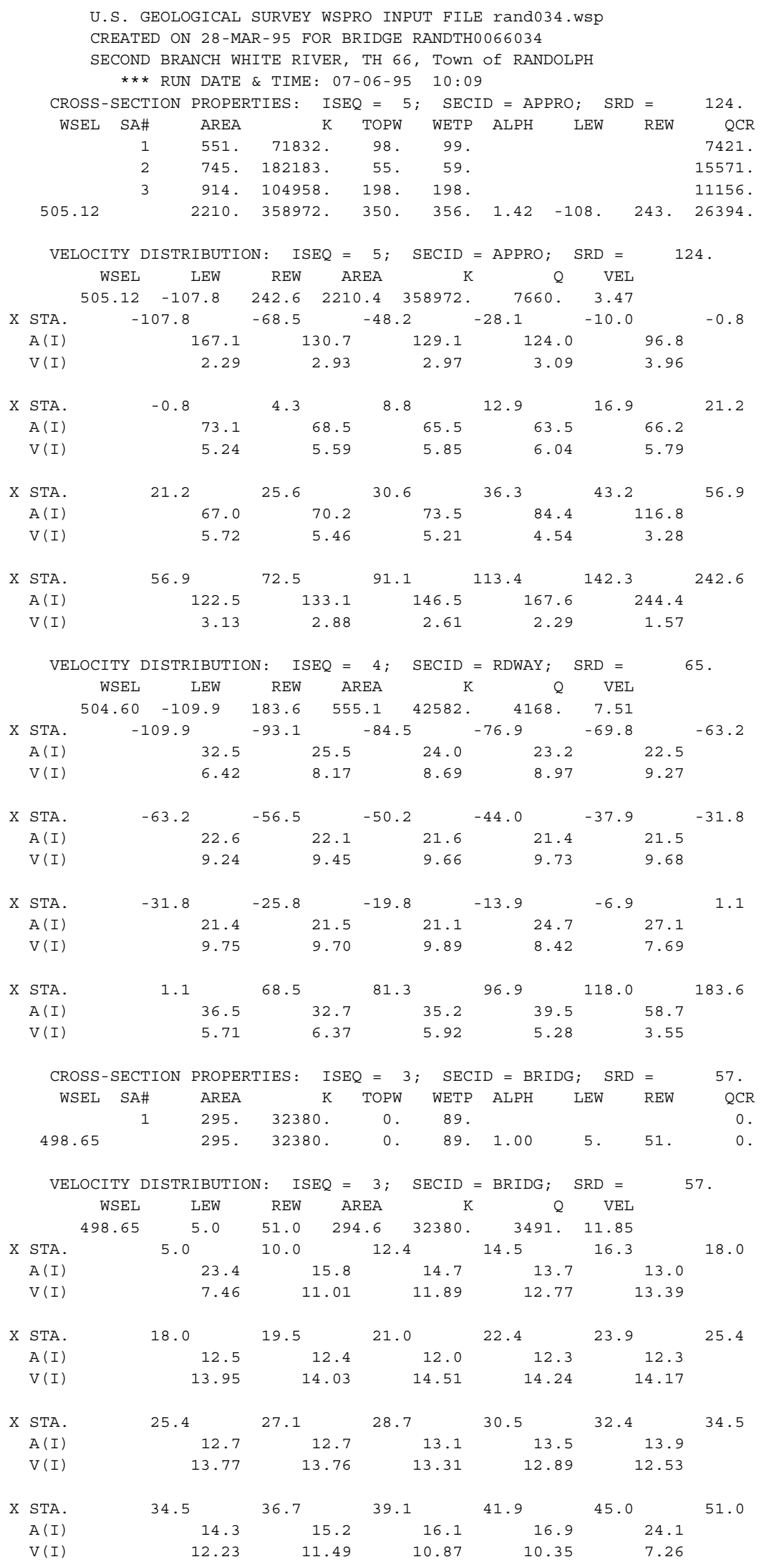


WSPRO OUTPUT FILE (continued)

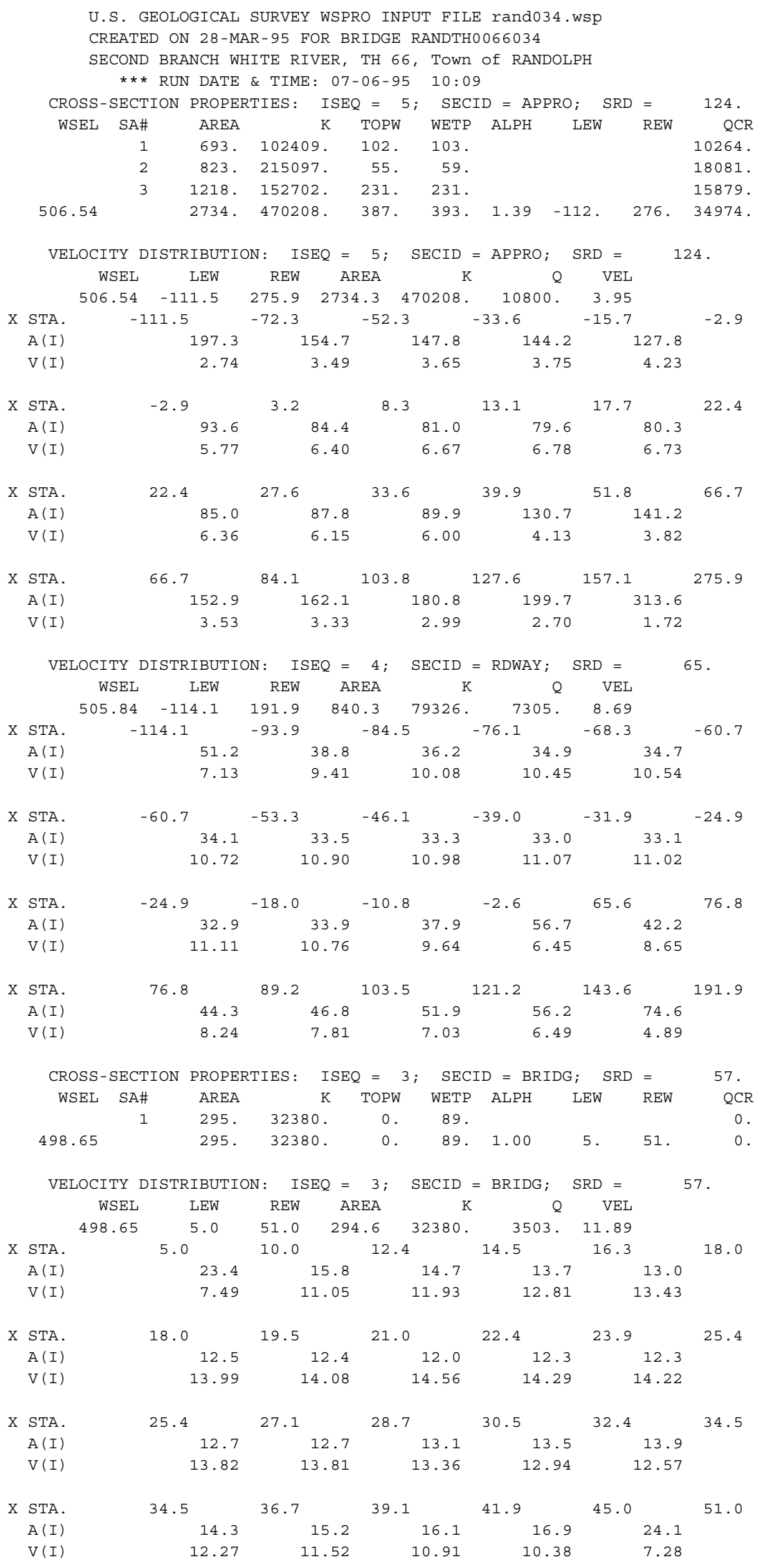


WSPRO OUTPUT FILE (continued)

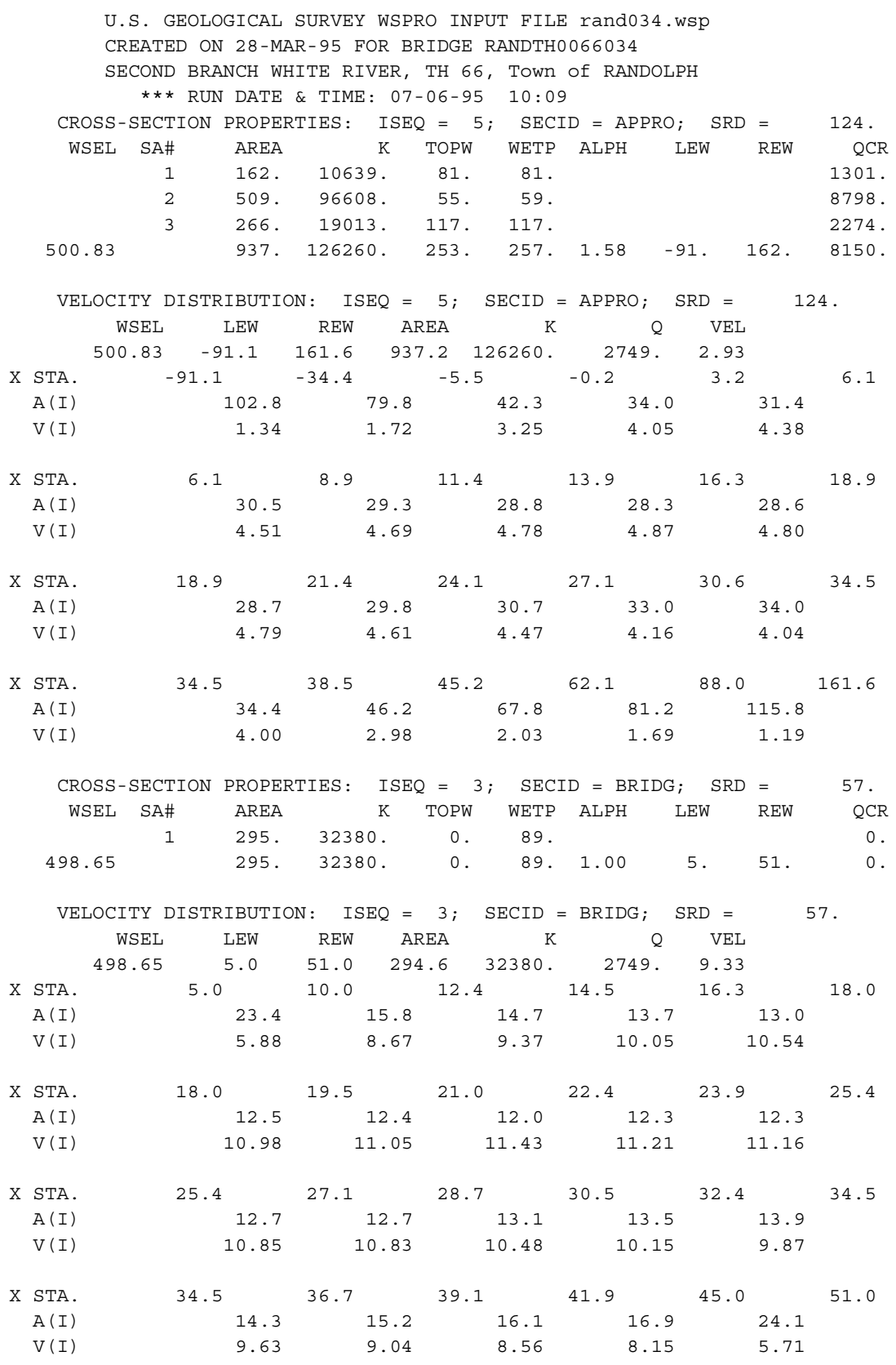


WSPRO OUTPUT FILE (continued)

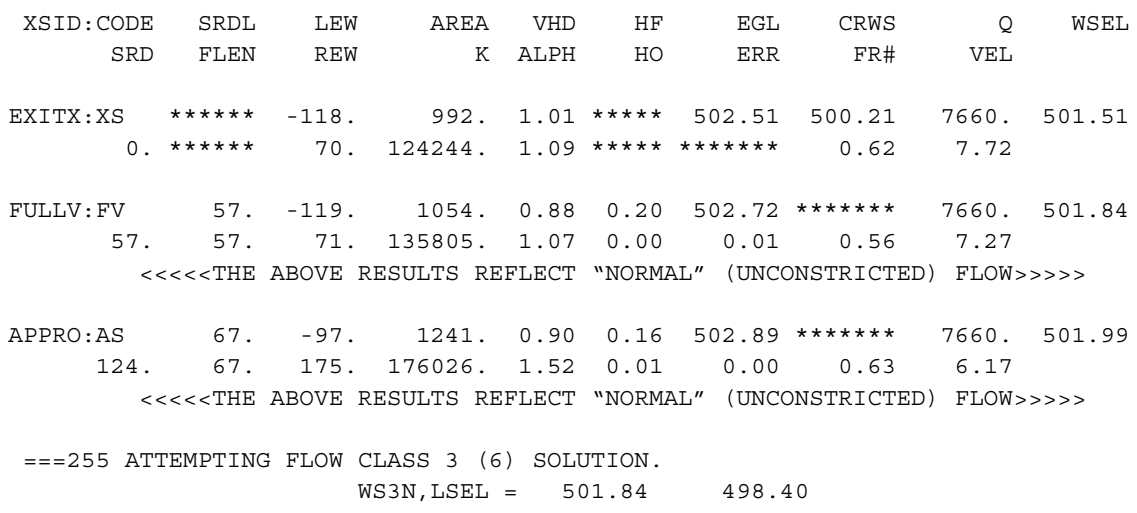


WSPRO OUTPUT FILE (continued)

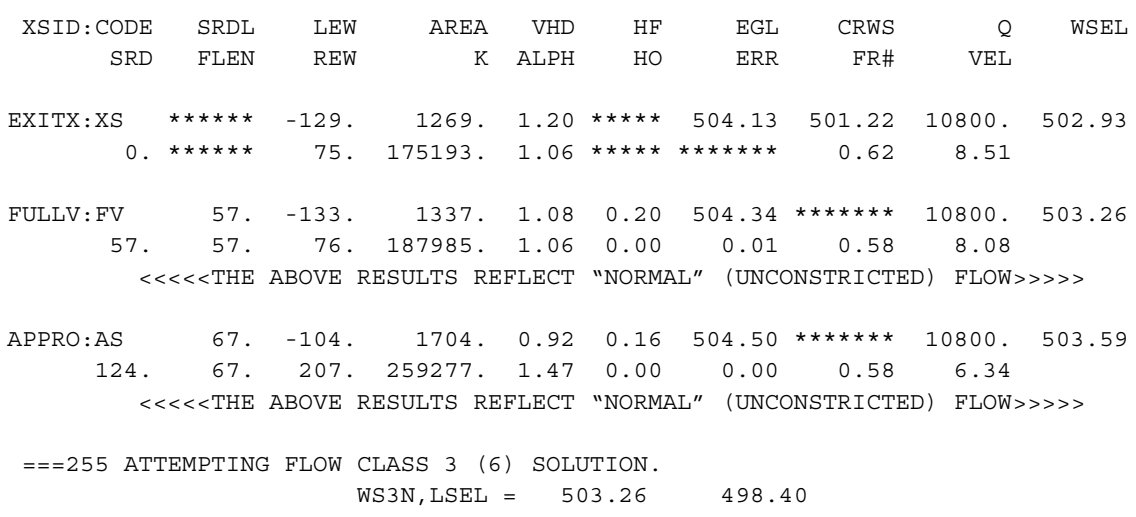


WSPRO OUTPUT FILE (continued)

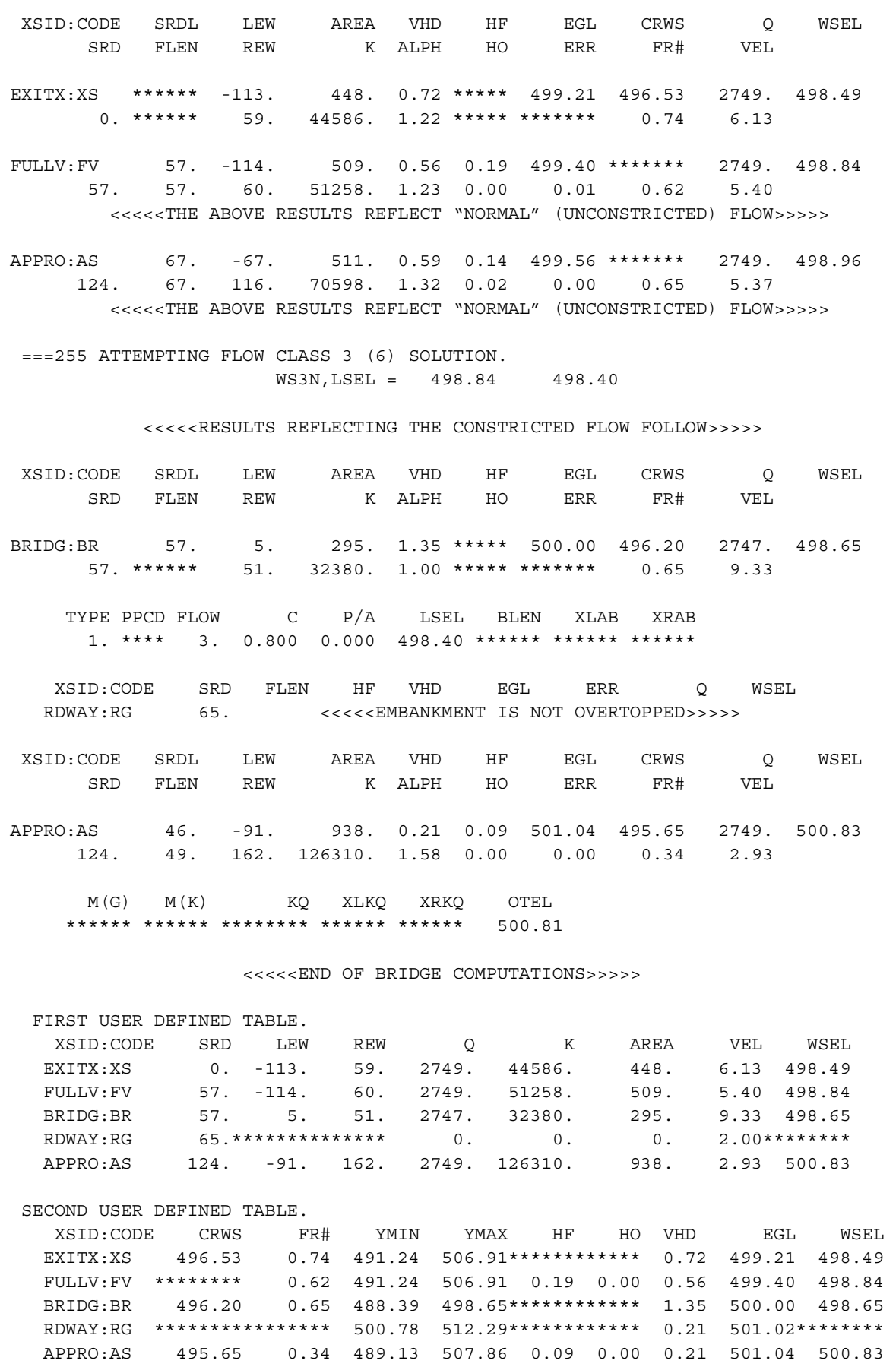




\section{APPENDIX C:}

\section{BED-MATERIAL PARTICAL-SIZE DISTRIBUTION}




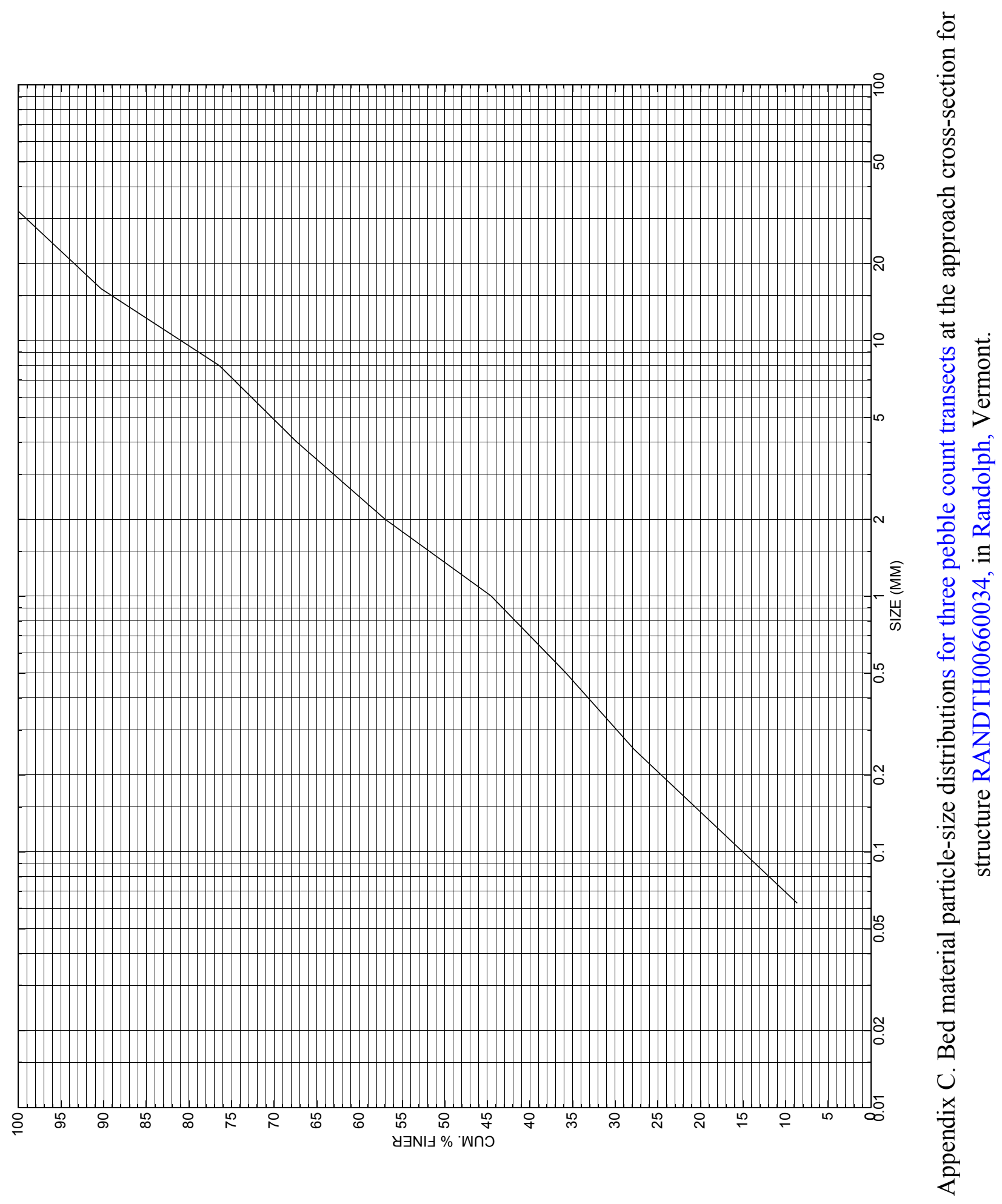




\section{APPENDIX D: \\ HISTORICAL DATA FORM}

